\title{
Self-assembled RGD dehydropeptide hydrogels for drug delivery applications
}

Article

Accepted Version

Vilaça, H., Castro, T., Costa, F. M. G., Melle-Franco, M., Hilliou, L., Hamley, I. W., Castanheira, E. M. S., Martins, J. A. and Ferreira, P. M. T. (2017) Self-assembled RGD dehydropeptide hydrogels for drug delivery applications. Journal of Materials Chemistry B, 5 (43). pp. 8607-8617. ISSN 0959-9428 doi: https://doi.org/10.1039/c7tb01883e Available at https://centaur.reading.ac.uk/73467/

It is advisable to refer to the publisher's version if you intend to cite from the work. See Guidance on citing.

To link to this article DOI: http://dx.doi.org/10.1039/c7tb01883e

Publisher: Royal Society of Chemistry

All outputs in CentAUR are protected by Intellectual Property Rights law, including copyright law. Copyright and IPR is retained by the creators or other copyright holders. Terms and conditions for use of this material are defined in the End User Agreement.

\section{www.reading.ac.uk/centaur}

\section{CentAUR}


Central Archive at the University of Reading

Reading's research outputs online 


\section{ARTICLE}

Cite this: DOI: 10.1039/xoxxooooox

Received ooth

Accepted ooth

DOI: $10.1039 /$ xoxxooooox

www.rsc.org/

\section{Self-assembled RGD dehydropeptide hydrogels for drug delivery applications}

\author{
Helena Vilaça, ${ }^{a}$ Tarsila Castro,,${ }^{a, b}$ Fernando M. G. Costa,${ }^{c}$ Manuel Melle-Franco,${ }^{b, d}$ Loic \\ Hilliou, ${ }^{e}$ Ian W. Hamley, ${ }^{f}$ Elisabete M. S. Castanheira, ${ }^{c}$ José A. Martins ${ }^{* a}$, Paula M. T. \\ Ferreira*a
}

\begin{abstract}
Combining a minimalist naproxen $\mathrm{N}$-capped dehydrodipeptide hydrogelator block with a peptide bioepitope, illustrated in this work by the Npx-L-Ala-Z- $\Delta$ Phe-G-R-G-D-G-OH construct, is an efficient approach to produce functional hydrogels.
\end{abstract}

Peptide-based self-assembled hydrogels trigged remarkable research interest in recent years owing to biocompatibility and biomimetic properties and responsiveness, which warrant many technological and biomedical applications. Dehydrodipeptides $N$-capped with naproxen emerged from our research as effective hydrogelators endowed with resistance to proteolysis. Dehydrodipeptide-based hydrogels are promising nanocarriers for drug delivery applications. In this work we demonstrate that dehydrodipetide Npx-L-Ala- $Z-\Delta \mathrm{Phe}-\mathrm{OH}$ can be deployed as a minimalist hydrogelator module for synthesizing a gelating construct Npx-L-Ala-Z- $\Delta$ Phe-G-R-G-D-G-OH bearing a GRGDG adhesion motif. The self-assembly of the peptide construct and the drug delivery properties of the hydrogel were studied in this work. The peptide construct showed no toxicity towards a fibroblast cell line expressing the $\alpha_{5} \beta_{3}$ integrin. Docking studies suggest that the hydrogelator block does not interfere with the recognition of the RGD motif by the integrin receptor. The Self-assembly seems to be directed by intermolecular naftalene $\pi-\pi$ stacking interactions, with the peptide backbone assuming a random coil conformation both in solution and in gel phase. TEM and STEM imaging revealed that the hydrogel is made of entangled bundles of long thin fibres (width circa $23 \mathrm{~nm}$ ). The hydrogel exhibits viscoelastic properties, thermo-reversibility and recovery after mechanical fluidization. FRET studies showed that curcumin incorporated into the hydrogel interacts non-covalently with the hydrogel fibrils. Delivery of curcumin from the hydrogel into Nile-red loaded model membranes (SUVs) was demonstrated by FRET.

Naproxen $N$-capped dehydrodipeptides are efficacious minimalist hydrogelator modules for obtaining hydrogels functionalized with peptide ligands for cell receptors. These hydrogels are potential nanocarriers for drug delivery.

\section{Introduction}

An increase of the span of human live to unprecedented levels it is to be expected during this century. This will certainly demand future developments in areas such as tissue engineering and regenerative medicine. Unnatural scaffolds, structural and functional surrogates of the Extracellular Matrix (ECM), are essential to foster future developments on stem cell therapies, tissue engineering and regenerative medicine. ${ }^{1}$ Beyond its role as structural scaffold for cell growth, the ECM presents a variety of physical, chemical and biochemical cues to cells that direct adhesion, differentiation, proliferation and migration. ${ }^{2}$ Micro- nanostructured matrices that create a highly hydrated porous $3 \mathrm{D}$ environment are the most promising ECM surrogates. Synthetic and natural polymer-based hydrogels ${ }^{3}$ and self-assembled hydrogels ${ }^{4}$ are the most efficacious scaffolds for tissue engineering. In nature, complex functional biological structures are built by spontaneous hierarchical assembly, self-assembly, of a limited number of simpler blocks driven by an array of cooperative non-covalent interactions: electrostatic, dipoledipole, van der Waals, $\pi-\pi$ stacking and hydrogen bonding. ${ }^{5}$ Selfassembly has become also the privileged methodology for bottomup construction of complex nanostructured materials in the lab. In addition to a plethora of natural building blocks, synthetic (unnatural) blocks can be designed for specific applications. ${ }^{5,6}$ Amino acids and peptides are privileged blocks for self-assembly into complex micro/nanostructured objects owing to availability and variety of building blocks, amenability to chemical synthesis and tuneable structure and function. ${ }^{7}$ Peptide-based self-assembled hydrogels trigged remarkable research interest in recent years owing to biocompatibility and biomimetic properties, with a plethora of technological and biomedical applications. ${ }^{4,7,8,9}$ Peptide sequences (motifs) responsible for peptide/protein self-assembly (aggregation) 
in vivo/vitro can be simplified into self-assembling low molecular weight peptides (hydrogelators), amenable to chemical synthesis and (bio)chemical elaboration. ${ }^{7,8,9}$ The peptide sequences RGD and IKVAV, displayed by ECM proteins vitronectin and laminin, respectively, are important biochemical cues (epitopes). ${ }^{10}$ Recognition of the RGD and IKVAV epitopes by cell receptors triggers responses such as cell migration and differentiation. ${ }^{11}$ Peptide-based hydrogels are made of hydrated networks of selfassembled fibrils. Peptide constructs containing self-assembly modules and biochemical epitopes originate fibrils with the selfassembly module at the core, decorated with hydrophilic/charged pendant epitopes, available for interaction with biological receptors. Minimalist self-assembly peptide motifs can generate nanofibres presenting high density display (per mass unit of hydrogelator) of pendant epitopes. ${ }^{12,13}$ A precise hydrophobicity/hydrophilicity balance and hydrogen bonding (donor/acceptor) properties seem crucial for self-assembly. $C$-deprotected amino-acids and dipeptides $N$-capped with bulky aromatic moieties e.g. fluorenylmethoxycarbonyl (Fmoc), naphthaloyl (Nap), naproxyl $(\mathrm{Npx})$, are efficacious minimalist hydrogelators., ${ }^{4,9}$ Fmoc-capped phenylalanine (Fmoc-F) and phenylalanylphenylalanine (Fmoc-FF) are well characterized minimalist hydrogelator modules able to trigger self-assembly of peptide constructs bearing $C$-terminal RGD epitopes. ${ }^{12,13}$ Hydrogels with tuneable density display of RGD epitopes were obtained by co-assembly of non-gelating Fmoc-RGD peptide with hydrogelator Fmoc-FF. ${ }^{13}$ Simultaneous presentation of ECM epitopes RGD and IKVAV on hydrogel nanofibrils was demonstrated recently by co-assembly of Fmoc-FFRGD and FmocFIKVAV hydrogelators. Co-assembled hydrogels showed improved biological properties comparing to single-epitope and post-assembly mixed hydrogels. ${ }^{12}$ Potential biological applications of Fmoc-capped peptide hydrogelators are compromised by the narrow $\mathrm{pH}$ stability window of the Fmoc group and toxicity issues related to its decomposition by-products and precipitation. ${ }^{14,15}$

Peptide-based hydrogelators/hydrogels are particularly sensitive to proteolysis by endogenous proteases. Incorporation of nonproteinogenic amino-acids into peptides can enhance proteolytic stability and add conformational restraints to the peptide backbone. ${ }^{16}$ Nontoxic, self-assembled hydrogels, resistant to proteolysis and responsive to stimuli were built from dehydrodipeptide $\mathrm{H}-\mathrm{Phe}-\Delta \mathrm{Phe}-$ $\mathrm{OH}$ (Phe- $\Delta \mathrm{Phe})$, containing a dehydrophenylalanine ( $\Delta \mathrm{Phe})$ residue. ${ }^{17}$ A $3 \mathrm{D}$ hydrogel scaffold able to sustain cell penetration and growth was prepared by chemical elaboration of the pre-formed Phe- $\Delta$-Phe hydrogel with a RGD (RGDGG) epitope. ${ }^{18}$ Bing Xu and co-workers demonstrated for the first time that $L$-Phe- $L$-Phe and $D$ Phe- $D$-Phe dipeptides $N$-capped with Non-Steroidal AntiInflammatory Drugs (NSAID), specifically naproxen, $(R S)$ flurbiprofen and $(R)$-flurbiprofen, and $(R S)$-ibuprofen are effective hydrogelators. ${ }^{19}$ Importantly, the same authors disclosed that naproxen $N$-capped peptides based on the unnatural dipeptide motif $D$-Phe- $D$-Phe not only retain the NSAID activity of naproxen but display enhanced selectivity for the Cyclooxygenase-2 (COX-2) enzyme. ${ }^{20}$ Recently, Cui and co-workers demonstrated that $(S)$ ketoprofen $N$-capped peptides $L$-VEVE and $D$-VEVE display also enhanced selectivity for COX-2, despite significant reduction of activity comparing to the unconjugated NSAID. ${ }^{21}$ In previous works we demonstrated that dehydrodipeptides $N$-capped with naproxen (Npx) are non-toxic to cells, stable towards proteolysis and produce hydrogels displaying rheological properties suitable for biological applications. $^{22}$ The NSAID properties of the naproxen capping moiety are likely retained by the hydrogelator molecules. ${ }^{20,21}$
Napoxen $N$-capped dehydrodipeptide-based hydrogels were proposed as potential nanocarriers for drug delivery. ${ }^{23}$

In this work we explore dehydrodipetide Npx-L-Ala-Z- $\Delta \mathrm{Phe}-\mathrm{OH}$ as a minimalist hydrogelator module for synthesizing a gelating construct Npx-L-Ala-Z- $\Delta$ Phe-G-R-G-D-G-OH bearing a GRGDG adhesion motif. The self-assembly of the peptide construct and the drug delivery properties of the hydrogel were studied. The effect of the chirality of the hydrogelator block Npx-L-Ala-Z- $\Delta \mathrm{Phe}-\mathrm{OH}$ on the self-assembly and drug delivery properties of the peptide construct was not addressed in this study.

\section{Results and discussion}

Synthesis

Peptide construct Npx-L-Ala-Z- $\Delta$ Phe-G-R-G-D-G (4), consisting of a proteolysis-stable minimalist hydrogelator module Npx-L-Ala-Z- $\Delta$ Phe-OH (Naproxenalanyldehydrophenylalanine) (1) and a pentapeptide (GRGDG) RGD epitope was synthesized by combined solution and solid phase peptide synthesis. The hydrogelator block was prepared by a procedure previously described by us (Scheme 1). ${ }^{19,21}$ The pentapeptide block GRGDG was synthesized by solid phase peptide synthesis on chlorotrityl chloride resin by the fluorenyl9-methoxycarbonyl (Fmoc) protocol. Pbf (2,2,4,6,7pentamethyldihydrobenzofuran-5-sulfonyl) and tert-butyl ester groups were deployed for arginine and aspartic acid side chain protection, respectively. Peptides were elongated using Fmocamino acids under diisopropylcarbodiimide (DIC) and 1hydroxybenzotriazole (HOBt) coupling conditions. The hydrogelator block (1) was coupled to the solid phase anchored GRGDG pentapeptide using the DIC/HOBt protocol (Scheme 1). The hydrogelator-RGD peptide construct was cleaved from the resin using 2,2,2-trifluoroethanol in acetic acid and further deprotected by treatment with trifluoroacetic acid. The hydrogelator-RGD peptide construct Npx-L-Ala-Z- $\Delta$ Phe-G-RG-D-G (4) was obtained as TFA salt in $45 \%$ overall yield.

The structure of the peptide construct was confirmed by 1D and 2D ${ }^{1} \mathrm{H}$ and ${ }^{13} \mathrm{C}$ NMR techniques and Mass Spectrometry. The $Z$-stereochemistry of dehydrophenylalanine residue was confirmed by NOE difference experiments.

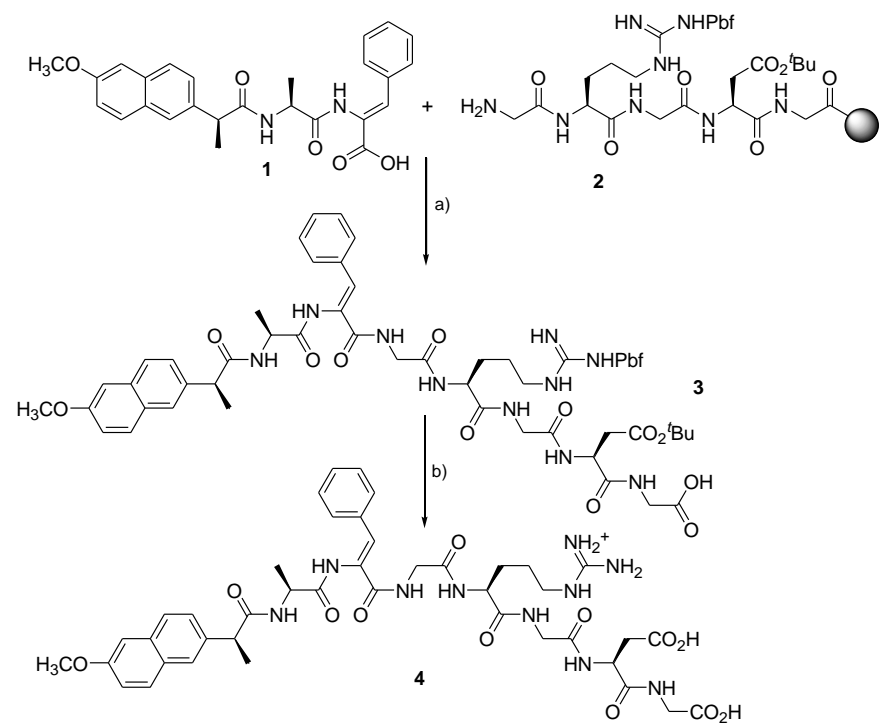


Scheme 1. Synthesis of hydrogelator-RGD peptide construct Npx-LAla-Z- $\Delta$ Phe-Gly-Arg-Gly-Asp-Gly-OH (4): a) i) HOBt, DIC, DMF, rt, $18 \mathrm{~h}$, ii) AcOH/TFE/DCM (1:1:3), rt, $4 \mathrm{~h}$; b) TFA, rt, 5 h.

Peptide construct Npx-L-Ala-Z- $\Delta$ Phe-G-R-G-D-G (4) afforded well defined hydrogels in the concentration range $0.32-0.40$ wt\% (Figure 1, Figure S1). Gels revealed stable at room temperature for extended time periods. It seems plausible to ascribe the gelation ability of peptide construct 4 to the aggregation propensity of the hydrogelator module (1). Interestingly, peptide construct $\mathbf{4}$ displays a critical gelation concentration $(c g c)(0.32 \mathrm{wt} \%$, phosphate buffer $0.1 \mathrm{M}, \mathrm{pH} 6.0)$ significantly lower than hydrogelator block $1(0.8 \mathrm{wt} \%, \mathrm{pH}$ 5.0). ${ }^{22}$ The soluble, charged pentapeptide block GRGDG seems to contribute to self-assembly, presumably through intermolecular salt bridges.
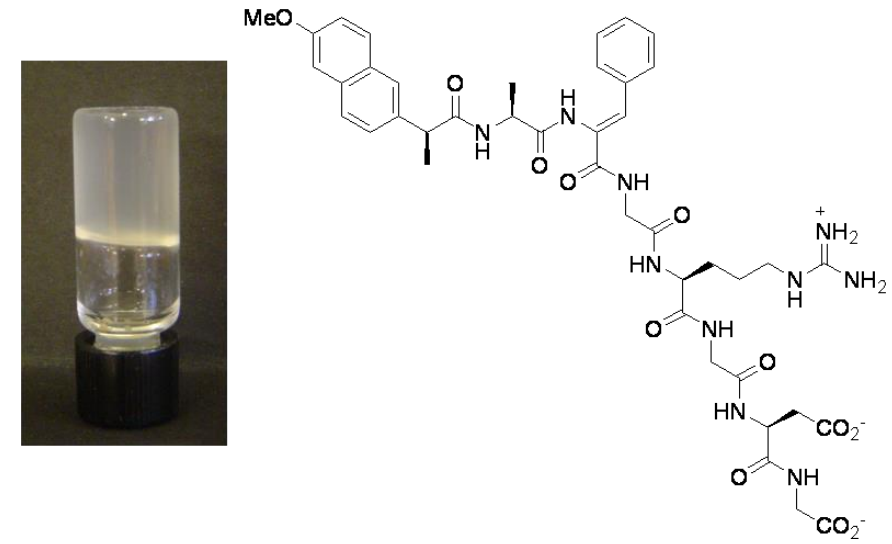

Figure 1. Hydrogel of peptide construct $4(0.32 \mathrm{wt} \%$, phosphate buffer $0.1 \mathrm{M}, \mathrm{pH} 6.0$ ).

\section{Fluorescence Spectroscopy Studies}

The intrinsic fluorophore naproxen allows to probe the properties of peptide construct (4) both in solution and in gel phase. ${ }^{22,23}$ The fluorescence of peptide construct $\mathbf{4}$ is dominated by naproxen emission $\left(\lambda_{\max }=353 \mathrm{~nm}, \lambda_{\mathrm{exc}}=290 \mathrm{~nm}\right)$ (Figure 2). The fluorescence emission of peptide 4 shows a weak dependence of the solution $\mathrm{pH}$ for peptide concentrations well below the $\operatorname{cgc}\left(2 \times 10^{-6} \mathrm{M}\right.$; phosphate buffer $\left.0.1 \mathrm{M}\right)$ (Figure S2).

The concentration dependence of the fluorescence emission of peptide construct 4 (phosphate buffer, $0.1 \mathrm{M}, \mathrm{pH}$ 6) shows a decrease in intensity, accompanied by bathochromic shift, of the naproxen band $\left(\lambda_{\max } \sim 350 \mathrm{~nm}, \lambda_{\mathrm{exc}}=290 \mathrm{~nm}\right)$, with increasing hydrogelator concentration. A subtle increase in emission around $430 \mathrm{~nm}$ becomes evident in the normalised spectra (inset A, Figure 2) suggesting the formation of intermolecular aggregates..$^{22,23}$

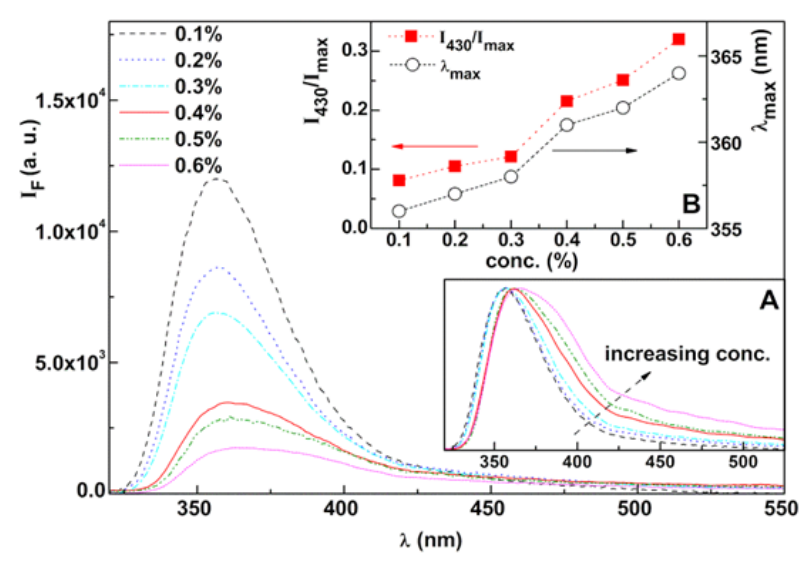

Figure 2. Concentration dependence of the fluorescence emission of peptide construct 4 (phosphate buffer $0.1 \mathrm{M}, \mathrm{pH} 6, \lambda_{\mathrm{exc}}=290 \mathrm{~nm}$ ). Insets: A: Normalized spectra. B: Concentration dependence of the wavelength of maximum emission $\left(\lambda_{\max }\right)$; ratio between the emission intensity at $430 \mathrm{~nm}$ and at $\lambda_{\max }\left(\mathrm{I}_{430} / \mathrm{I}_{\max }\right)$.

The concentration dependence of the ratio of emission intensities at $430 \mathrm{~nm}$ and at $\lambda_{\max }\left(\mathrm{I}_{430} / \mathrm{I}_{\max }\right)$ together with the shift of the wavelength of maximum emission of naproxen, point to hydrogel formation $(\mathrm{cgc})$ around $0.3-0.4 \mathrm{wt} \%$, in accordance to the value determined experimentally.

\section{Circular Dichroism}

The circular dichroism (CD) spectrum of the hydrogel of peptide construct 4 (0.32 wt $\%$, phosphate buffer $0.1 \mathrm{M}, \mathrm{pH} 6.0)$ displays a negative band in the far UV region $(202 \mathrm{~nm}$ ) characteristic of "random coil" conformation of the peptide backbone, i.e. lack of repetitive secondary structure (Figure 3). ${ }^{24}$ The strong positive band in the near UV region of the CD spectrum $(300 \mathrm{~nm})$ is assigned to supramolecular chirality of the naphthalene group of naproxen ( $\pi-\pi *$ transitions). ${ }^{25}$ The CD spectrum of the mechanically broken gel (solution phase) (Figure 3) shows a significant reduction in intensity of the positive Cotton effect at circa $300 \mathrm{~nm}$ accompanied by enhancement of the negative band at around $200 \mathrm{~nm}$. This suggests that $\pi-\pi$ stacking interactions of the naphthalene groups of the naproxen moieties play an important role in peptide self-assembly. ${ }^{22,23}$ 


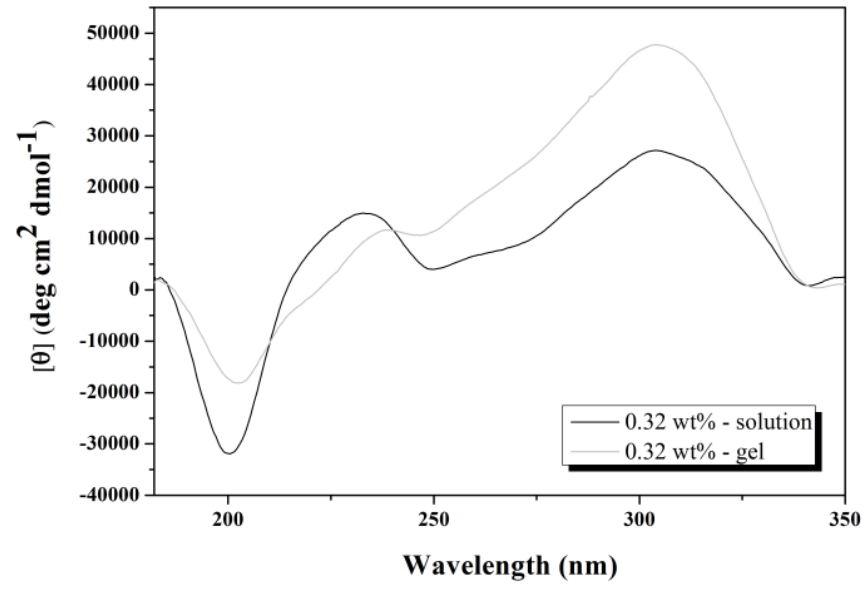

Figure 3. CD spectra of peptide construct, 4 (0.32 wt $\%$, phosphate buffer, $0.1 \mathrm{M}, \mathrm{pH} 6.0,25{ }^{\circ} \mathrm{C}$ ) in hydrogel phase and in solution (mechanically broken gel).

\section{TEM Analysis}

The micro/nanostructure of the hydrogel of peptide construct 4 (phosphate buffer $0.1 \mathrm{M}, \mathrm{pH}$ 6.0) was studied by Transmission Electron Microscopy (TEM) (Figure 4). TEM images were obtained with solutions of peptide construct $(0.06 \mathrm{wt} \%$; phosphate buffer, $0.1 \mathrm{M}, \mathrm{pH} 6)$ well below the $\operatorname{cgc}(0.32 \mathrm{wt} \%$; phosphate buffer, $0.1 \mathrm{M}, \mathrm{pH} 6.0$ ).

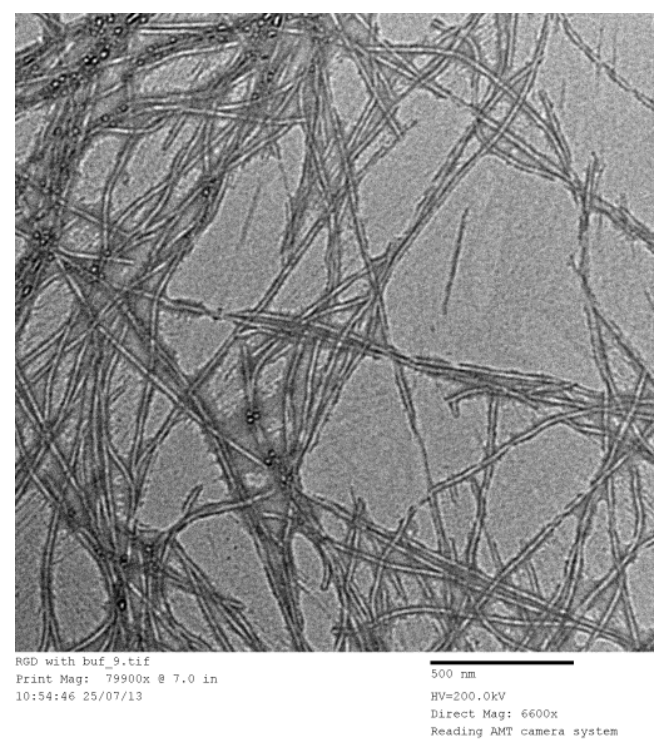

Figure 4. TEM image of dried solution of peptide construct $4(0.060$ wt $\%$; phosphate buffer $0.1 \mathrm{M}, \mathrm{pH} 6.0$ ) stained with uranyl acetate (scale bar $500 \mathrm{~nm}$ ).

TEM images revealed that peptide construct 4 self-assembles into a dense network of long nanofibres displaying an average width of $23 \mathrm{~nm}$. The fibres show some degree of flexibility and crosslinking.

\section{Rheology}

Viscoelastic properties are essential for biomedical applications of hydrogels. ECM surrogates must undergo fast and reproducible gelation under mild conditions, be amenable to handling at physiological temperature and $\mathrm{pH}$, and display mechanical properties that resemble natural tissue (elasticity $0.1-100 \mathrm{kPa}$ ) while sustaining long term cell culture. ${ }^{26}$ The rheological properties of hydrogel of peptide construct $\mathbf{4}$ and of hydrogelator block $\mathbf{1}$ are summarized in Table 1.

Table 1. Rheological properties of hydrogel of peptide construct (4) (0.50 wt\%, phosphate buffer 0.1 M, pH 6.0).

\begin{tabular}{|c|c|c|c|c|c|c|}
\hline \multirow{2}{*}{\multicolumn{2}{|c|}{ Hydrogel }} & \multicolumn{2}{|c|}{$\begin{array}{c}\text { Dynamic frequency } \\
\text { sweep }^{c}\end{array}$} & \multicolumn{3}{|c|}{ Dynamic strain sweep ${ }^{g}$} \\
\hline & & $\mathrm{G}^{\prime}[\mathrm{Pa}]$ & $\mathrm{G}^{\prime \prime}[\mathrm{Pa}]$ & $\mathrm{G}^{\prime}[\mathrm{Pa}]$ & $\mathrm{G}^{\prime}[\mathrm{Pa}]$ & Critical \\
\hline \multirow[t]{4}{*}{$4^{a}$} & \multirow{2}{*}{$\begin{array}{l}1^{\text {st }} \\
\text { cycle }^{\mathrm{d}}\end{array}$} & 581 & 32 & 1240 & 56 & 3.3 \\
\hline & & $38^{\mathrm{f}}$ & $4^{\mathrm{f}}$ & -- & -- & -- \\
\hline & \multirow{2}{*}{$\begin{array}{l}2^{\text {nd }} \\
\text { cycle }\end{array}$} & 171 & 11 & 192 & 13 & 1.0 \\
\hline & & $247^{\mathrm{f}}$ & $18^{\mathrm{f}}$ & -- & -- & -- \\
\hline $\mathbf{1}^{\mathrm{b}}$ & & 800 & 117 & 590 & 110 & 0.3 \\
\hline
\end{tabular}

[a] This work; [b] ref. 22; [c] values at $f=1 \mathrm{~Hz}, \gamma=0.5 \%, \mathrm{~T}=20^{\circ} \mathrm{C}$, [d] after 30 minutes of structural build-up at $20^{\circ} \mathrm{C}$; [e] after 60 minutes of structural build-up at $20{ }^{\circ} \mathrm{C}$; [f] after shear breaking and 30 minutes $\left(1^{\text {st }}\right.$ cycle) or 60 minutes $\left(2^{\text {nd }}\right.$ cycle $)$ of structural build-up; [g] The values are taken at $f=1 \mathrm{~Hz}$ and $\mathrm{T}=20^{\circ} \mathrm{C}$.

Peptide construct 4 could be dissolved in phosphate buffer upon heating, followed by gel formation upon cooling to room temperature. The mature hydrogel could be re-dissolved upon heating and the heat/cool cycle could be repeated several times. The mechanical spectrum (Figure S3C), acquired following gel structural build-up for 30 minutes at $20^{\circ} \mathrm{C}$, revealed very weak frequency dependence of the storage modulus $\left(G^{\prime}\right)$. Moreover, the storage modulus is over 10 times larger than the loss modulus $\left(G^{\prime \prime}\right)$ (cycle 1 , Table 1 ) indicating a strong physical gel in contrast to weak gels. ${ }^{27}$ The dynamic strain sweep spectrum (Figure S3D) reveals that despite a low critical strain ( $3 \%$ ) for onset of yielding a large strain (in excess of $100 \%$ ) is required to fluidize the gel. The mechanically fluidized gel, when allowed to rebuild for 30 minutes, still shows (Figure $\mathrm{S} 3 \mathrm{~F}$ ) a storage modulus 10 times larger than the loss modulus, despite significantly lower values for both $G$ ' and $G$ ', (weaker gel). Thus, this gel exhibits self-healing. ${ }^{28}$ A longer time, 60 minutes at $20{ }^{\circ} \mathrm{C}$, was required for rebuilding the gel re-heated to $65^{\circ} \mathrm{C}$ (cycle 2) (Figure S4). A weaker gel, characterised by significantly lower values for $G^{\prime}$ and $G$ ' ' and critical strain, was obtained in cycle II comparing to cycle I (Table 1, Figure S4CD). The mechanically fluidized gel from cycle II, when allowed to rebuild for 60 minutes, showed fully recovery of both storage and loss moduli (Table 1, Figure S4F). The hydrogel of peptide construct 4 shows thermo-reversibility and partial recovery of viscoelastic properties, following mechanical fluidization, properties that are relevant for biological applications. The elasticity of the hydrogel after first breaking up or re-heating approaches the lower limit of elasticity of soft biological tissues, which might constitute a limitation for specific biological applications. 
Nanocarrier for Drugs

We proposed before that the hydrogel of dehydrodipeptide Npx-L-Trp-Z- $\Delta$ Phe-OH is a potential nanocarrier for drug delivery applications. ${ }^{22}$ In this work we further advance this concept using the hydrogel of peptide construct $\mathbf{4}$ as nanocarrier and curcumin as a model drug.

Curcumin has gained much attention as a potential therapeutic agent owing to a plethora of biological activities: antiinflammatory, antimicrobial, antioxidant and anticancer and high dose tolerance. ${ }^{29}$ Nonetheless, high plasma concentrations of curcumin, required for therapeutic purposes, can be attained only through delivery strategies owing to low solubility in aqueous media and low bioavailability. ${ }^{30}$ Curcumin is fluorescent in several polar and non-polar media, exhibiting intramolecular charge transfer (ICT) in the excited state as well as hydrogen bonding in protic solvents. ${ }^{31}$

Curcumin was incorporated into the hydrogel (0.4-0.5 wt\%, phosphate buffer $0.1 \mathrm{M}, \mathrm{pH}$ ), as ethanolic solution (total ethanol content bellow 1\%), during the gelation phase. Direct excitation of curcumin incorporated into the hydrogel results in strong emission $\left(\lambda_{\max }\right.$ circa $525 \mathrm{~nm}, \lambda_{\mathrm{exc}}=410 \mathrm{~nm}$ ) indicating that curcumin molecules are entrapped/associated with the hydrogel fibres, sensing an environment with polarity equivalent to acetonitrile (Figure S5 and S6). Spectral overlap between hydrogel emission and curcumin absorption allowed to study the interaction hydrogel/curcumin by FRET (Förster Resonance Energy Transfer). ${ }^{32}$ Curcumin emission above 480 $\mathrm{nm}$ and reduction of hydrogel emission, upon excitation of the hydrogel aromatic groups $\left(\lambda_{\text {exc }}=290 \mathrm{~nm}\right)$, was ascribed to FRET (Figure 5).

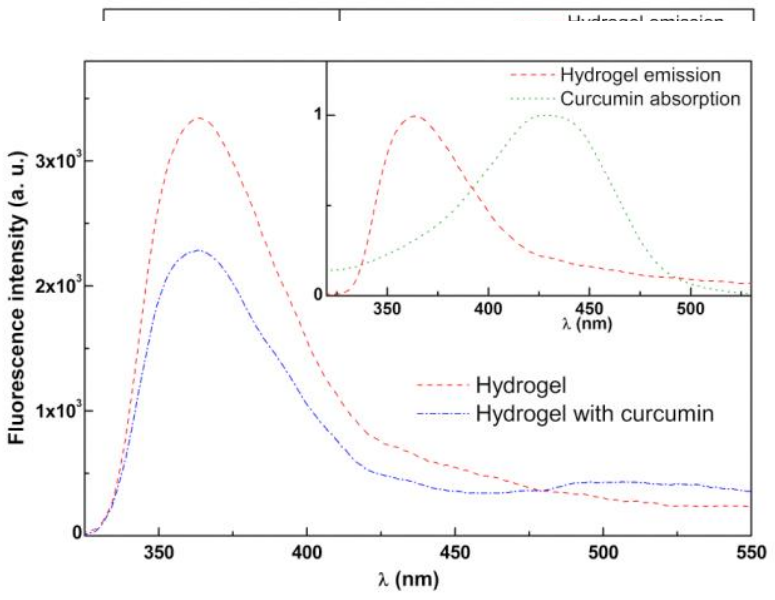

Figure 5. Fluorescence spectra $\left(\lambda_{\mathrm{exc}}=290 \mathrm{~nm}\right)$ of hydrogel of dehydrodipeptide 4 (0.4 wt\%; phosphate buffer $0.1 \mathrm{M}$, pH 6.0) with curcumin incorporated $\left(3 \times 10^{-6} \mathrm{M}\right)$. Inset: Spectral overlap (normalized spectra) between hydrogel emission and curcumin absorption in ethanol.

Fluorescence anisotropy measurements (Table 2) further support molecular association between curcumin and the hydrogel. ${ }^{33}$ The FRET efficiency $\left(\Phi_{\text {RET }}\right.$ ) and the corresponding donor-acceptor distances were calculated using equations 3-6 (see Experimental Section) (Figure 5, Table 2). $R_{0}$ and $r_{A D}$ represent the Förster radius (critical distance) and the donoracceptor interaction distances, respectively. The fluorescence quantum yield of the hydrogel (energy donor; $\Phi_{D}=0.011$ ) was determined using the standard method (equation 1, Experimental Section).

Hydrogel concentration has a significant effect on FRET efficiency and on the curcumin-hydrogel interaction distances. The calculated distances curcumin-hydrogel are of the same order of magnitude as those obtained (also by FRET) for noncovalent binding of curcumin to Human Serum Albumin (HSA) $\left(\Phi_{\text {RET }}=0.33 ; R_{0}=27.44 \AA ; r_{A D}=30.95 \AA\right) .{ }^{34}$ These results strongly suggest a host/guest type molecular interaction between the hydrogel fibres (host) and curcumin (guest).

Lipophilic/amphiphilic hydrogelators are prone to interact with cell membranes potentially leading to membrane disruption and/or cell lysis. The interaction between the hydrogel and model lipidic membranes (Small Unillamellar Vesicles- SUVs of egg phosphatidylcholine/cholesterol 7:3) was studied by incorporating the FRET donor-acceptor pair curcumin-Nile red into SUVs. ${ }^{35,36}$ The fluorescence quantum yield of curcumin in this type of SUVs (in the absence of Nile red) was determined as $\Phi_{\mathrm{D}}=0.069$. Pronounced Nile red emission $\left(\lambda_{\max }=625 \mathrm{~nm}\right)$ was observed in SUVs upon excitation of curcumin $\left(\lambda_{\text {exc }}=410\right.$ $\mathrm{nm}$ ) (Figure 6). Interaction between the SUVs and the hydrogel results only in a slight increase of the donor-acceptor distance, with a corresponding reduction of FRET efficiency (Figure 6 and Table 2). Therefore, the SUVs seem to maintain their integrity in the presence of the hydrogel.

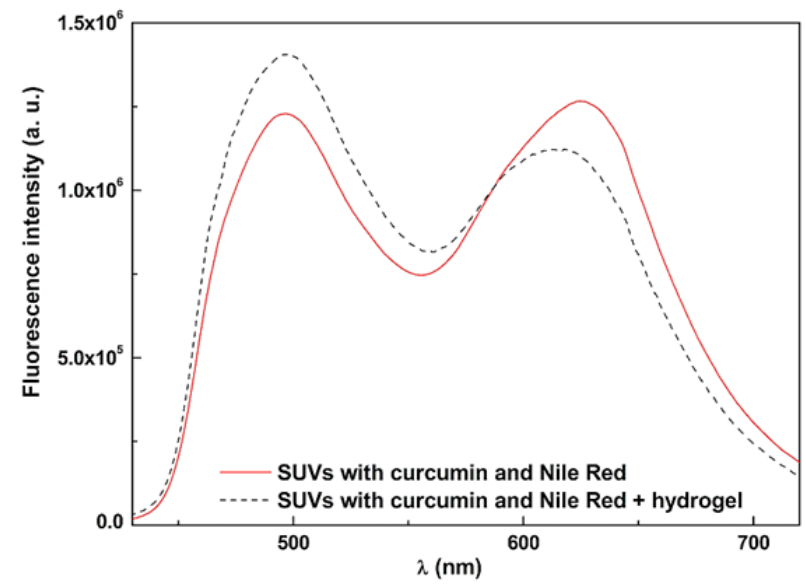

Figure 6. Fluorescence spectra $\left(\lambda_{\text {exc }}=410 \mathrm{~nm}\right.$, negligible direct Nile red excitation) of SUVs (egg lecithin/cholesterol 7:3) loaded with curcumin and Nile red, before and after interaction with the hydrogel $(0.4 \mathrm{wt} \%$; phosphate buffer 0.1 M, pH 6.0).

To ascertain the drug delivery potential of the hydrogel we studied the interaction between the hydrogel loaded with curcumin $\left(1 \times 10^{-5} \mathrm{M}\right)$ and SUVs loaded with Nile red (Figure 7). The interaction results in hypsochromic shift of the waveength of maximum emission of curcumin $\left(\lambda_{\max } 530 \rightarrow 500 \mathrm{~nm}, \lambda_{\mathrm{exc}}=\right.$ $410 \mathrm{~nm})$ and strong Nile red emission $\left(\lambda_{\max }=625 \mathrm{~nm}\right)$. 


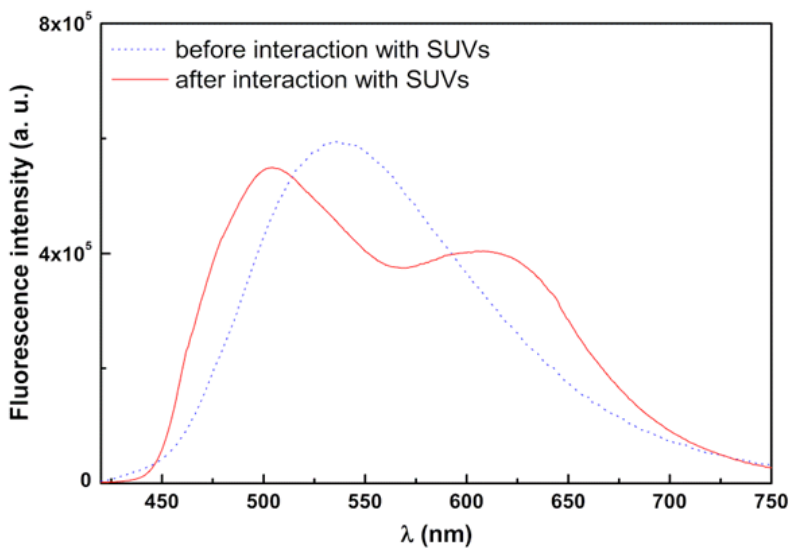

Figure 7. Fluorescence spectra $\left(\lambda_{\text {exc }}=410 \mathrm{~nm}\right)$ of hydrogel $(0.4 \%$ concentration) loaded with curcumin $\left(1 \times 10^{-5} \mathrm{M}\right)$, before and after interaction with SUVs containing only Nile red.

Table 2. FRET efficiencies and donor-acceptor distances for the hydrogel-curcumin pair and fluorescence anisotropy values for curcumin incorporated into the hydrogel (line 1 and 2) and FRET efficiencies and donor-acceptor distances for the curcumin-Nile red pair in SUVs (line 3 and 4).

\begin{tabular}{l|c|c|c|c}
\hline & $\boldsymbol{\Phi}_{\mathbf{R E T}}$ & $\boldsymbol{R}_{\mathbf{0}}(\mathbf{\AA})$ & $\boldsymbol{r}_{\mathrm{AD}}(\mathbf{A})$ & $\begin{array}{c}\text { anisotropy, } \\
\boldsymbol{r}\end{array}$ \\
\hline $\begin{array}{l}\text { Hydrogel 0.4 wt\% } \\
\text { loaded with curcumin }\end{array}$ & 0.31 & 22.8 & 26.1 & 0.276 \\
\hline $\begin{array}{l}\text { Hydrogel 0.5 wt\% } \\
\text { loaded with curcumin }\end{array}$ & 0.51 & 23.0 & 22.7 & 0.279 \\
\hline $\begin{array}{l}\text { SUVs loaded with } \\
\text { curcumin and Nile red }\end{array}$ & 0.372 & & 40.1 & -- \\
\hline $\begin{array}{l}\text { SUVs loaded with } \\
\text { curcumin and Nile red } \\
\text { upon interaction with } \\
\text { hydrogel }\end{array}$ & 0.281 & 36.8 & 43.0 & -- \\
\hline
\end{tabular}

These results strongly suggest transference of curcumin from the hydrogel to the lipidic membranes (SUVs) establishing drug delivery potential for this gel. Moreover, the RGD epitope potentially endows the hydrogel with ability for interacting with cell membranes presenting integrin receptors (overexpressed in cancer cells).

\section{Docking and MD Simulations}

Molecular recognition of the RGD epitope of hydrogelator 4 by cells (over)expressing the $\alpha_{v} \beta_{3}$ integrin receptor can conceptually be used for cell homing to the nanofibres and delivery of growth factors or therapeutic agents. ${ }^{37}$ The molecular recognition of peptide construct 4 by the $\alpha_{\mathrm{v}} \beta_{3}$ integrin receptor was studied by molecular docking using AutoDock 4.2. ${ }^{38}$ The binding energy and the geometry of peptide construct 4 in interaction with the $\alpha_{\mathrm{v}} \beta_{3}$ integrin were computed (Figure 8 and Table 3 ). The X-ray structure of the cyclic RGD ligand cyclo(RGDf[N-Me]V, bound to the extracellular fragment of the $\alpha_{\mathrm{v}} \beta_{3}$ integrin was used as reference benchmark. ${ }^{39}$ The experimental geometry could be reproduced with a root mean square deviation of $0.23 \mathrm{~nm}$ for the heavy atoms, validating the docking parameters.
Table 3. Binding energy for the lowest energy conformations (arrangement $\mathrm{A}$ and $\mathrm{B}$, Figure 8) of peptide construct $\mathbf{4}$ and for the cyclo(RGDf $[N$-Me $] \mathrm{V}$ peptide in interaction with the $\alpha_{v} \beta_{3}$ integrin.

\begin{tabular}{l|c|c|c}
\hline \multirow{2}{*}{ Ligand } & $\begin{array}{c}\text { cyclo(RGDf }[N- \\
\text { Me]V) }\end{array}$ & \multicolumn{2}{|c}{ Peptide 4 } \\
\cline { 3 - 4 } & -11.75 & Pose A & Pose B \\
\hline$\Delta \mathrm{G}_{\text {bind }}(\mathrm{kcal} / \mathrm{mol})$ & -14.44 & -14.93 & -12.24 \\
\hline Intermolecular & & & -14.93 \\
Energy $(\mathrm{kcal} / \mathrm{mol})$ & & & \\
\hline
\end{tabular}

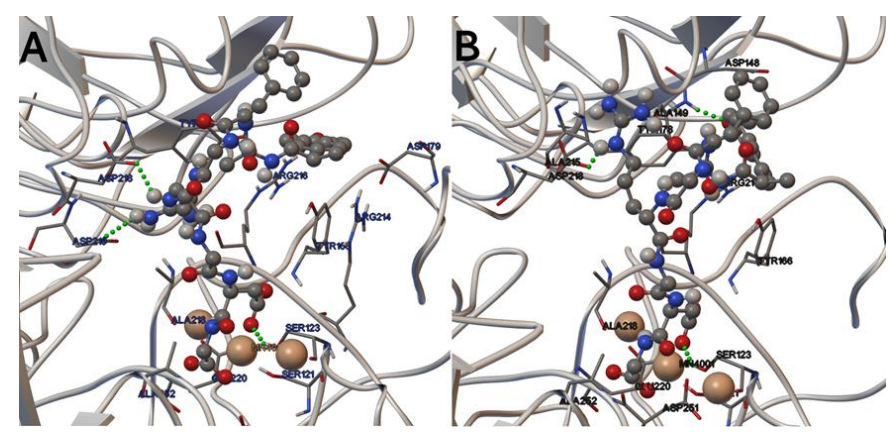

Figure 8. Representation of the interactions between the degenerate lowest binding energy conformations of peptide construct 4 (A- arrangement A and B- arrangement) and $\alpha_{v} \beta_{3}$ integrin. The protein is represented as cartoon. Sticks are used to highlight the protein residues that make contact interactions with the ligand. The $\mathrm{Mn}^{2+}$ ions are shown as brown larger spheres.

The lowest binding energy conformations identified for peptide construct 4 in interaction with the $\alpha_{\mathrm{v}} \beta_{3}$ integrin are degenerate (arrangement A and B- Figure 8). Peptide construct 4 is positioned between the $\alpha$ and $\beta$ chains of the integrin exhibiting a pose similar to that found for the cyclo(RGDf[N-Me]V) ligand in the X-Ray structure of the $\alpha_{\mathrm{v}} \beta_{3}$ integrin receptor. The arginine residue of the peptide construct interacts through hydrogen bonding with the Asp218 residue of the integrin receptor. The aspartate residue interacts via a salt bridge with a $\mathrm{Mn}^{2+}$ metal ion on the integrin binding site, reproducing the interaction seen in the experimental structure. ${ }^{39}$ An additional hydrogen bond, not seen in the experimental structure, is established between the aspartate residue of the RGD module and the Ser193 residue of the integrin. The deprotonated $C$ terminal of peptide 4 interacts with a (different) $\mathrm{Mn}^{2+}$ metal ion in the integrin binding site. The hydrogelator module Npx-LAla-Z- $\Delta$ Phe of the peptide construct seems not to hinder the molecular recognition between RGD epitope and the $\alpha_{v} \beta_{3}$ integrin receptor. Combining the hydrogelator module with other targeting epitopes could be a viable strategy for producing hydrogels with tailor-made cell specificity.

\section{In Vitro Studies}

For drug delivery purposes the hydrogelator (and hydrogel) must be nontoxic and biocompatible. The toxicity of peptide construct 4 and of the hydrogelator block Npx-L-Ala-Z- $\Delta$ Phe-OH (1) was evaluated with the integrin expressing human skin dermal fibroblasts cell line ASF-2 by the MTT assay (Figure 9). 


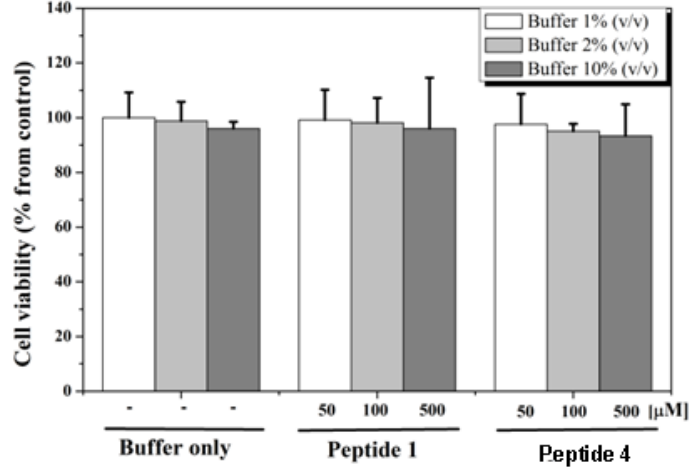

Figure 9. Evaluation of cell viability of adult human skin fibroblasts by the MTT test after 48 hours incubation with peptide construct 4 and hydrogelator block $1(50 \mu \mathrm{M}, 100 \mu \mathrm{M}$ or $500 \mu \mathrm{M} ; 10 \%$ phosphate buffer $\mathrm{pH}$ 6.0, 0.1 $\mathrm{M}$ in DEMEM cell growth medium). No significant differences were observed $(\mathrm{P}>0.05)$.

Hydrogelator block 1 and peptide construct 4 seem not to exhibit toxicity in solution in the concentration range 50-500 $\mu \mathrm{m}$ (Figure 8). It seems that combining the hydrogelator module 1 with the RGD targeting module does not elicits conjugate toxicity. ${ }^{22,23}$ The lack of toxicity of the peptide construct suggests that the hydrogel might also be biocompatible. Further studies are necessary to evaluate the biocompatibility of the hydrogel of peptide construct 4 . It is plausible that the polar charged RGD module is exposed to the solvent in the hydrogel fibrils creating a dense multivalent display of epitopes available for interaction with integrin receptors on cells. ${ }^{12,13}$

\section{Proteolytic stability studies}

In previous studies we demonstrated that the naproxen $N$-capped dehydrodipeptide hydrogelators Npx- $L-\mathrm{Phe}-Z-\Delta-\mathrm{Phe}-\mathrm{OH}$ and Npx- $L$ Phe-Z- $\Delta-\mathrm{Abu}-\mathrm{OH}$ are resistant to proteolysis by chymotrypsin. Peptide Npx- $L$-Phe- $L$-Phe-OH readily undergoes proteolysis under the same experimental conditions. ${ }^{22}$ Thus, the proteolytic stability of the dehydrodipeptides can be ascribe $d$ to steric, conformational and/or electronic effects of the dehydroaminoacid in the scissile peptide bond. Peptide 4 was incubated with chymotrypsin and the reaction was monitored by HPLC $(\lambda=276 \mathrm{~nm}$; water/acetonitrile, $1: 1$ with $0.1 \%$ TFA) following the disappearance of the substrate 4 and the formation of a proteolytic fragment (Figure 10).

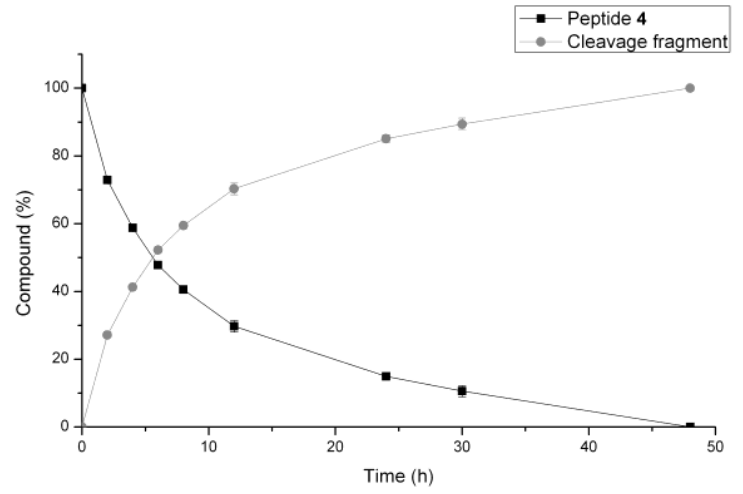

Figure 10. Evaluation of the proteolitic stability of peptide 4 in the presence of $\alpha$-chymotrypsin ( $\mathrm{pH} 7.4,37^{\circ} \mathrm{C}$ ) over 48 hours.
Peptide 4 undergoes proteolytic degradation by chymotrypsin with $50 \%$ remaining after 6 hours incubation. The reaction is complete after 48 hours. $\mathrm{Xu}$ and co-workers reported before that peptides $\mathrm{H}-L$ Phe-R-G-D-OH and H- $L$-Phe- $L$-Phe-R-G-D-OH $N$-capped with nucleobases and $C$-amidated with glucosamine undergo hydrolysis by proteinase $\mathrm{K}$, a protease with broad specificity for aromatic and aliphatic amino acids. ${ }^{40}$ HPLC-MS (ESI, positive ionization) monitoring of the reaction revealed that the proteolytic fragment displays $m / z$ values 660 and 682, assigned to the sequence Npx- $L$ Ala-Z- $\Delta$ Phe-G-R-OH $\left([\mathrm{M}+\mathrm{H}]^{+}\right.$and $[\mathrm{M}+\mathrm{Na}]^{+}$, respectively) (Figure S7). Chymotrypsin is specific to peptide bonds were the amino acid residue on the carboxyl side (residue P1) carries an aromatic side chain (Phe, Trp, Tyr residues). Thus, it is unlikely that the proteolytic fragment observed results from chymotrypsin catalysis. The formation of this fragment is plausible through the action of the enzyme trypsin- selective towards positively charged amino acid residues (Lys, and Arg residues) on position P1. In fact, trypsin and chymotrypsin are mutual trace contaminants commonly found in enzyme preparations obtained from bovine pancreas. This serendipitous result shows that the $\Delta$ Phe residue makes the peptide hydrogelator block resistant to hydrolysis by chymotrypsin. Nonetheless, the dehydroamino acid seems not to prevent hydrolysis at positions downstream in the peptide chain. This result is important as a fine balance between proteolytic stability and degradability of peptide-based hydrogels is fundamental for biological applications.

\section{Conclusions}

In this work we demonstrate that the naproxen $N$-capped dehydrodipeptide Npx-L-Ala-Z- $\Delta$ Phe is a stable minimalist hydrogelator able to trigger gelation of a RGD construct. Peptide construct Npx-L-Ala-Z- $\Delta$ Phe-G-R-G-D-G (4) revealed nontoxic to cells. Molecular recognition in silico of the RGD adhesion motif by the $\alpha_{\mathrm{v}} \beta_{3}$ integrin receptor seems not to be hindered by the hydrogelator module. The peptide construct self-assembles in aqueous buffer into hydrogels made of entangled bundles of long fibers. The peptide backbone seems to assume a random coil conformation both in solution and gel phase. $\pi-\pi$ stacking interactions of the naproxen moieties of the hydrogelator module seem to play an important role on peptide self-assembly. The hydrogel exhibits viscoelastic properties and partial recovery after mechanical fluidization. Curcumin incorporated into the hydrogel senses an environment with a polarity equivalent to acetonitrile with FRET distances of the same order of magnitude as those obtained for non-covalent binding of curcumin to HSA/BSA. The hydrogel seems not to disrupt SUVs model membranes. Importantly, we were able to demonstrate by FRET transfer of curcumin from the hydrogel into Nile-Red loaded SUVs. Further studies are necessary to evaluate hydrogel biocompatibility and drug delivery to cells. In this work peptide construct Npx-L-Ala-Z-APhe-G-R-G-D-G$\mathrm{OH}$ is used as proof of concept that combining minimalist naproxen N-capped dehydrodipeptide hydrogelators with peptide bioepitopes is an efficient approach to produce functional hydrogels. The rheological and drug delivery properties of the hydrogels can plausibly be fine-tuned by the structure of the hydrogelator block. 


\section{Experimental}

Melting points $\left({ }^{\circ} \mathrm{C}\right)$ were determined in a Gallenkamp apparatus and are uncorrected. ${ }^{1} \mathrm{H}$ and ${ }^{13} \mathrm{C}$ NMR spectra were recorded on a Bruker Avance III at 400 and $100.6 \mathrm{MHz}$, respectively, or in a Varian Unity Plus 300 at 300 and $75.4 \mathrm{MHz}$, respectively. ${ }^{1} \mathrm{H}-$ ${ }^{1} \mathrm{H}$ spin-spin decoupling and DEPT $\theta 45^{\circ}$ were used. HMQC and HMBC were used to attribute some signals. Chemical shifts $(\delta)$ are given in parts per million (ppm) and coupling constants $(J)$ in Hertz $(\mathrm{Hz})$. High resolution mass spectrometry (HRMS) data were recorded by the mass spectrometry service of the University of Vigo, Spain. Elemental analysis was performed on a LECO CHNS 932 elemental analyzer. Column chromatography was performed on Macherey-Nagel silica gel 230-400 mesh. Petroleum ether refers to the boiling range 40$60{ }^{\circ} \mathrm{C}$. Solid Phase Peptide Synthesis (SPPS) was carried out using 2-chlorotrytil chloride resin (100-200 mesh) 1\% DVB, with a loading capacity of $1.4 \mathrm{mmol} \mathrm{g}^{-1}$. All solutions were made up with ultra filtered $(18 \mathrm{M} \Omega$ ) water from a Barnstead Nanopure system. Phosphate buffers were prepared from $\mathrm{NaH}_{2} \mathrm{PO}_{4}$ and $\mathrm{Na}_{2} \mathrm{HPO}_{4}$ with a final concentration of $0.1 \mathrm{~m}$. Phosphate-buffered saline (PBS) was prepared from $2.7 \mathrm{~mm}$ $\mathrm{KCl}, 137 \mathrm{~mm} \mathrm{NaCl}, 10 \mathrm{~mm} \mathrm{Na} \mathrm{HPO}_{4} .2 \mathrm{H}_{2} \mathrm{O}$ and $1.8 \mathrm{~mm}$ $\mathrm{KH}_{2} \mathrm{PO}_{4}$ with $\mathrm{pH} 7.39$.

\section{Synthesis}

Dehydrodipeptide Npx-L-Ala-Z- $\Delta$ Phe-OH (1) was synthesized following the methodology previously described by us. ${ }^{22}$

Synthesis of Npx-L-Ala-Z-APhe-Gly-L-Arg $(P b f)-G l y-L-A s p\left(O^{t} B u\right)$ Gly-OH (3): Fmoc-Gly-OH (1.20 equiv (resin), $0.50 \mathrm{~g}, 1.68 \mathrm{mmol})$ was dissolved in dry DCM (10 mL). DIPEA (4.00 equiv (Fmoc-Gly$\mathrm{OH}), 1.16 \mathrm{~mL}, 6.72 \mathrm{mmol})$ and the resin $(1.00 \mathrm{~g})$ were added. The mixture was left stirring at room temperature for 6 hours. The resin was filtered and washed successively with a mixture of DCM/MeOH/DIPEA $(17: 2: 1,3 \times 10 \mathrm{~mL})$, DCM $(3 \times 10 \mathrm{~mL})$, DMF $(3 \times 10 \mathrm{~mL})$ and DCM $(3 \times 10 \mathrm{~mL})$. The resin was left drying under reduced pressure overnight. Resin loading $\left(0.89 \mathrm{mmol} \mathrm{g}^{-1}\right)$ was calculated by measuring by the absorbance of the dibenzofulvenepiperidine adduct at $290 \mathrm{~nm}$. After washing the resin with DMF $(2 \times 10 \mathrm{~mL})$, a solution of $20 \%$ piperidine in DMF $(10 \mathrm{~mL})$ was added. The mixture was left stirring at $\mathrm{rt}$ for 2 hours. The resin was filtered and washed successively with DMF $(2 \times 10 \mathrm{~mL}), 2$-propanol $(2 \times 10 \mathrm{~mL}), \mathrm{DMF}(2 \times 10 \mathrm{~mL})$ and 2 -propanol $(2 \times 10 \mathrm{~mL})$. The TNBS test was used to verify the cleavage of the Fmoc group. Fmoc-L$\mathrm{Asp}\left(\mathrm{O}^{t} \mathrm{Bu}\right)-\mathrm{OH}$ (3.00 equiv) 1-hydroxybenzotriazole (HOBt) $(3.00$ equiv) and $N, N^{\prime}$-diisopropylcarbodiimide (DIC) (3.00 equiv) were dissolved in DMF $(10 \mathrm{~mL})$. The solution was added to the resin and the mixture was left stirring at room temperature overnight. The resin was filtered and washed successively with DMF $(3 \times 10 \mathrm{~mL})$ and DCM $(3 \times 10 \mathrm{~mL})$. The coupling was verified by the TNBS test. The cleavage of the Fmoc group and coupling of the amino acids were repeated for Fmoc-Gly-OH (3.00 equiv), Fmoc-L-Arg(Pbf)-OH (3.00 equiv), Fmoc-Gly-OH (3.00 equiv) and peptide 1 (2.00 equiv). A mixture of AcOH/TFE/DCM $(1: 1: 3,20 \mathrm{~mL})$ was added to the resin and it was left stirring at room temperature for 4 hours. The solution was filtered and the solvent removed under reduced pressure. Precipitation with diethyl ether afforded compound $3(0.55$ $\mathrm{g}, 51 \%)$ as a pale pink solid; ${ }^{1} \mathrm{H}$ NMR $\left(400 \mathrm{MHz}, \mathrm{DMSO}-d_{6}, \delta\right): 1.29$ (d, $\left.J=6.8 \mathrm{~Hz}, 3 \mathrm{H}, \mathrm{CH}_{3} \mathrm{Ala}\right), 1.34\left(\mathrm{~s}, 9 \mathrm{H}, 3 \times \mathrm{CH}_{3}\right), 1.34-1.42(\mathrm{~m}, 2 \mathrm{H}$, $\gamma \mathrm{CH}_{2} \mathrm{Arg}$ ), 1.38 (s, 6H, $\left.2 \times \mathrm{CH}_{3}\right), 1.41$ (d, $J=7.2 \mathrm{~Hz}, 3 \mathrm{H}, \mathrm{CH}_{3} \mathrm{Npx}$ ), 1.42-1.56 (m, 1H, $\beta \mathrm{CH}$ Arg), 1.61-1.70 (m, 1H, $\beta \mathrm{CH}$ Arg), 1.98 (s, $3 \mathrm{H}, \mathrm{CH}_{3} \mathrm{Pbf}$ ), 2.40-2.47 (m, 1H, $\beta \mathrm{CH}$ Asp), 2.41 (s, 3H, $\mathrm{CH}_{3} \mathrm{Pbf}$ ),
2.47 (s, 3H, $\mathrm{CH}_{3} \mathrm{Pbf}$ ), 2.65 (dd, $J=5.4$ and $15.8 \mathrm{~Hz}, 1 \mathrm{H}, \beta \mathrm{CH}$ Asp), 2.93 (s, $\left.2 \mathrm{H}, \mathrm{CH}_{2} \mathrm{Pbf}\right), 2.98-3.01\left(\mathrm{~m}, 2 \mathrm{H}, \delta \mathrm{CH}_{2} \mathrm{Arg}\right.$ ), 3.64-3.77 (m, $\left.6 \mathrm{H}, 3 \times \mathrm{CH}_{2} \mathrm{Gly}\right), 3.78-3.86(\mathrm{~m}, 1 \mathrm{H}, \mathrm{CH} \mathrm{Npx}), 3.84\left(\mathrm{~s}, 3 \mathrm{H}, \mathrm{OCH}_{3}\right)$, 4.24-4.30 (m, 1H, $\alpha \mathrm{CH}$ Arg), 4.37-4.41 (m, 1H, $\alpha \mathrm{CH}$ Ala), 4.61-4.67 (m, 1H, $\alpha \mathrm{CH}$ Asp), 6.59 (vbs, 2H, 2×NH Arg), 7.03 (brs, 1H, $\varepsilon \mathrm{NH}$ Arg), 7.08-7.11 (m, 1H, Ar H Npx), 7.10 (s, 1H, $\beta C H), 7.21-7.27$ (m, 4H, Ar H Npx, 3×Ar H $\Delta \mathrm{Phe}$ ), 7.43 (dd, $J=1.6$ and $8.8 \mathrm{~Hz}, 1 \mathrm{H}$, Ar H Npx), 7.49-7.51 (m, 2H, Ar H $\Delta$ Phe), 7.68-7.74 (m, 3H, Ar H Npx), 7.87 (d, $J=7.6 \mathrm{~Hz}, 1 \mathrm{H}, \alpha \mathrm{NH}$ Arg), 8.00-8.02 (m, 1H, NH

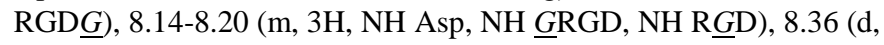
$J=6.0 \mathrm{~Hz}, 1 \mathrm{H}, \mathrm{NH}$ Ala), 9.72 (s, 1H, NH $\Delta \mathrm{Phe}) ;{ }^{13} \mathrm{C}$ NMR (100.6 MHz, DMSO-d,$\delta): 12.26\left(\mathrm{CH}_{3} \mathrm{Pbf}\right), 17.04\left(\mathrm{CH}_{3} \mathrm{Ala}\right), 17.59\left(\mathrm{CH}_{3}\right.$ $\mathrm{Pbf}), 18.94\left(\mathrm{CH}_{3} \mathrm{Npx}, \mathrm{CH}_{3} \mathrm{Pbf}\right), 25.26\left(\gamma \mathrm{CH}_{2} \mathrm{Arg}\right), 27.63\left(3 \times \mathrm{CH}_{3}\right)$, $28.29\left(2 \times \mathrm{CH}_{3}\right), 29.19\left(\beta \mathrm{CH}_{2} \mathrm{Arg}\right), 37.53\left(\beta_{\mathrm{CH}_{2}} \mathrm{Asp}\right), 41.18\left(\mathrm{CH}_{2}\right.$ Gly), $41.98\left(\mathrm{CH}_{2} \mathrm{Gly}\right), 42.45\left(\mathrm{CH}_{2} \mathrm{Pbf}\right), 42.72\left(\mathrm{CH}_{2} \mathrm{Gly}\right), 43.74$ $\left(\delta \mathrm{CH}_{2} \mathrm{Arg}\right), 44.41$ ( $\left.\mathrm{CH} \mathrm{Npx}\right), 48.87$ ( $\alpha \mathrm{CH}$ Ala), 49.25 ( $\left.\alpha \mathrm{CH} \mathrm{Asp}\right)$, $52.24(\alpha \mathrm{CH} \mathrm{Arg}), 55.11\left(\mathrm{OCH}_{3} \mathrm{Npx}\right), 80.16\left(\underline{\mathrm{C}}\left(\mathrm{CH}_{3}\right)_{3}\right), 86.27(2-\mathrm{C}$ Pbf), 105.65 (CH Npx), 116.25 (C Pbf), 118.44 (CH Npx), 124.31 (C Pbf), 125.42 (CH Npx), 126.49 (CH Npx), 126.60 (CH Npx), $128.32(\mathrm{C} \mathrm{Npx}), 128.36(\alpha \mathrm{C}), 128.41(2 \times \mathrm{CH} \Delta \mathrm{Phe}), 128.66(\mathrm{CH}$ $\Delta \mathrm{Phe}), 128.77$ ( $\beta \mathrm{CH} \Delta \mathrm{Phe}), 129.06(\mathrm{CH} \mathrm{Npx}), 129.54(2 \times \mathrm{CH}$ $\Delta \mathrm{Phe}), 131.42$ (C Pbf), 133.08 (C Npx), 133.72 ( $\left.\mathrm{C}_{\mathrm{i}} \Delta \mathrm{Phe}\right), 134.20$ (C Pbf), 137.09 (C-2 Npx), 137.25 (C Pbf), 156.16 (C=N Arg), 156.93 (C-6 Npx), 157.42 (C Pbf), 164.93 (C=O $\Delta \mathrm{Phe}), 168.60(\mathrm{C}=\mathrm{O}$ $\mathrm{R} \underline{G}$ ), 168.80 (C=O $\underline{G R G D), ~} 169.24$ (C=O Asp), 170.39 (C=O Asp), $171.06(\mathrm{C}=\mathrm{O} \operatorname{RGD} \underline{G}), 171.72$ ( $\mathrm{C}=\mathrm{O}$ Arg), 172.51 ( $\mathrm{C}=\mathrm{O}$ Ala), $173.98(\mathrm{C}=\mathrm{O} \quad \mathrm{Npx})$; HRMS (ESI) $m / z:[\mathrm{M}+\mathrm{H}]^{+}$calcd for $\mathrm{C}_{59} \mathrm{H}_{77} \mathrm{~N}_{10} \mathrm{O}_{15} \mathrm{~S}^{+}$1197.52851; found, 1197.52727 .

Synthesis of Npx-L-Ala-Z-APhe-Gly-L-Arg-Gly-L-Asp-Gly-OH,TFA (4): TFA (6 mL mmol-1) was added to Npx-L-Ala-Z- $\Delta$ Phe-Gly-L$\operatorname{Arg}(\mathrm{Pbf})-\mathrm{Gly}-\mathrm{L}-\mathrm{Asp}\left(\mathrm{O}^{\mathrm{t} B u}\right)-\mathrm{Gly}-\mathrm{OH}$ (2) (0.54 g, $\left.0.45 \mathrm{mmol}\right)$ and the mixture was left stirring at room temperature for 5 hours. The solvent was removed under reduced pressure. Diethyl ether was added and the solvent removed again under reduced pressure. Precipitation with diethyl ether afforded compound 4 (0.40 g, 89\%) as a beije solid; ${ }^{1} \mathrm{H}$ NMR $\left(400 \mathrm{MHz}, \mathrm{DMSO}-d_{6}, \delta\right): 1.30(\mathrm{~d}, J=6.8$ $\left.\mathrm{Hz}, 3 \mathrm{H}, \mathrm{CH}_{3} \mathrm{Ala}\right), 1.42$ (d, $\left.J=6.8 \mathrm{~Hz}, 3 \mathrm{H}, \mathrm{CH}_{3} \mathrm{Npx}\right), 1.49-1.55$ (m, $3 \mathrm{H}, \mathrm{CH}$ Arg), 1.68-1.77 (m, 1H, CH Arg), 2.48-2.49 (m, 1H, $\beta \mathrm{CH}$ Asp), 2.65-2.70 (m, 1H, $\beta \mathrm{CH}$ Asp), 3.06-3.08 (m, $2 \mathrm{H}, \delta \mathrm{CH}_{2} \mathrm{Arg}$ ), 3.69-3.76 (m, 6H, 3× $\mathrm{CH}_{2}$ Gly), 3.82-3.85 (m, 1H, CH Npx), 3.84 (s, $3 \mathrm{H}, \mathrm{OCH}_{3}$ ), 3.97 (brs, $3 \mathrm{H}, \mathrm{NH}_{3}^{+}$), 4.29-4.32 (m, 1H, $\alpha \mathrm{CH} \mathrm{Arg}$ ), 4.37-4.40 (m, 1H, $\alpha \mathrm{CH}$ Ala), 4.59-4.64 (m, 1H, $\alpha \mathrm{CH}$ Asp), 6.83 (brs, $1 \mathrm{H}, \mathrm{NH}), 7.09-7.12(\mathrm{~m}, 1 \mathrm{H}, \operatorname{Ar} \mathrm{H} \mathrm{Npx}), 7.11(\mathrm{~s}, 1 \mathrm{H}, \beta \mathrm{CH}), 7.22-$ $7.27(\mathrm{~m}, 4 \mathrm{H}, \mathrm{Ar} \mathrm{H}$ Npx, $3 \times \mathrm{Ar} \mathrm{H} \Delta \mathrm{Phe}), 7.42-7.45(\mathrm{~m}, 2 \mathrm{H}, \mathrm{Ar} H$ Npx, $\varepsilon N H$ Arg), 7.49-7.51 (m, 2H, 2×Ar H $\Delta$ Phe), 7.68-7.72 (m, 3H, $3 \times \operatorname{Ar} \mathrm{H} \mathrm{Npx}$ ), 7.90 (d, $J=8.0 \mathrm{~Hz}, 1 \mathrm{H}, \alpha \mathrm{NH}$ Arg), 8.12 (t, $J=5.8$ $\mathrm{Hz}, 1 \mathrm{H}, \mathrm{NH} \mathrm{RGD} \underline{G}), 8.16-8.22$ (m, 3H, NH Asp, NH $\underline{G} \mathrm{RGD}, \mathrm{NH}$ GRGD), 8.38 (d, $J=6.4 \mathrm{~Hz}, 1 \mathrm{H}, \mathrm{NH}$ Ala), 9.71 (s, 1H, NH $\Delta \mathrm{Phe}$ ); ${ }^{13} \mathrm{C}$ NMR (100.6 MHz, DMSO- $\left.d_{6}, \delta\right): 17.03\left(\mathrm{CH}_{3} \mathrm{Ala}\right), 18.95\left(\mathrm{CH}_{3}\right.$ Npx), $24.87\left(\mathrm{CH}_{2} \mathrm{Arg}\right), 29.06\left(\mathrm{CH}_{2} \mathrm{Arg}\right), 36.33$ ( $\left.\mathrm{CH}_{2} \mathrm{Asp}\right), 40.40$ $\left(\delta \mathrm{CH}_{2} \mathrm{Arg}\right), 40.81\left(\mathrm{CH}_{2} \mathrm{Gly}\right), 41.82\left(\mathrm{CH}_{2} \mathrm{Gly}\right), 42.73\left(\mathrm{CH}_{2} \mathrm{Gly}\right)$, 44.41 ( $\mathrm{CH}$ Npx), 48.92 ( $\alpha \mathrm{CH} \mathrm{Ala}), 49.30(\alpha \mathrm{CH} \mathrm{Asp}), 52.07(\alpha \mathrm{CH}$ Arg), $55.13\left(\mathrm{OCH}_{3} \mathrm{Npx}\right), 105.66(\mathrm{CH} \mathrm{Npx}), 118.47$ (CH Npx), 125.44 (CH Npx), 126.49 (CH Npx), 126.63 (CH Npx), $127.38(\alpha \mathrm{C})$, 128.33 (C Npx), $128.45(2 \times \mathrm{CH} \Delta \mathrm{Phe}), 128.74$ and 128.84 (CH $\Delta$ Phe and $\beta \mathrm{CH} \Delta \mathrm{Phe}), 129.08$ (CH Npx), $129.55(2 \times \mathrm{CH} \Delta \mathrm{Phe}), 133.09$ (C Npx), 133.68 ( $\left.\mathrm{C}_{\mathrm{i}} \Delta \mathrm{Phe}\right), 137.09$ (C-2 Npx), 156.61 (C=N Arg), 156.95 (C-6 Npx), 164.95 (C=O $\Delta$ Phe), 168.62 (C=O R $\underline{G D}), 168.83$ $(\mathrm{C}=\mathrm{O} \underline{G} \mathrm{RGD}), 170.93(\mathrm{C}=\mathrm{O}$ Asp and $\mathrm{C}=\mathrm{O} \mathrm{RGD} \underline{G}), 171.59$ and $171.61(\mathrm{C}=\mathrm{O}$ Arg and $\mathrm{C}=\mathrm{O}$ Asp $), 172.58(\mathrm{C}=\mathrm{O}$ Ala $), 174.08(\mathrm{C}=\mathrm{O}$ 
Npx); HRMS (ESI) $m / z$ : $[\mathrm{M}]^{+}$calcd for $\mathrm{C}_{42} \mathrm{H}_{53} \mathrm{~N}_{10} \mathrm{O}_{12}{ }^{+}$889.38389; found, 889.38563.

Self-assembly in buffer: Briefly, compounds were weighted into a sample vial, buffer was added and the mixture was heated to $80{ }^{\circ} \mathrm{C}$ and left to cool at room temperature or at $37^{\circ} \mathrm{C}$.

Vesicles preparation: Small unilamellar vesicles (SUVs) of egg-PC/cholesterol 7:3 were used as model membranes. 1,2diacyl-sn-glycero-3-phosphocholine from egg yolk (Egg-PC), and cholesterol (Ch) were obtained from Sigma-Aldrich. For SUVs preparation, defined volumes of stock solutions of lipids and dyes (curcumin and Nile red) in ethanol were injected together, under vigorous stirring, into aqueous buffer solution (10 $\mathrm{mM}$ Tris-HCl buffer, $\mathrm{pH}=7.4$ ), at room temperature (ethanolic injection method). ${ }^{35}$ The final total lipid concentration was $1 \mathrm{mM}$, with a dye/lipid molar ratio of 1:500.

Spectroscopic measurements: All solutions were prepared using spectroscopic grade solvents and Milli-Q grade water. For incorporating curcumin into hydrogels, a stock solution of curcumin in ethanol was added to the solution of hydrogelator during the gelation process. The ethanol content was kept below $1 \%$.

Absorption spectra were recorded in a Shimadzu UV-3101 PC UV-Vis-NIR spectrophotometer. Fluorescence measurements were performed using a Fluorolog 3 spectrofluorimeter, equipped with double monochromators in both excitation and emission, Glan-Thompson polarizers and a temperature controlled cuvette holder. Fluorescence spectra were corrected for the instrumental response of the system.

The fluorescence quantum yields, $\Phi_{\mathrm{s}}$, were determined by the standard method (equation 1), ${ }^{41}$

$$
\Phi_{\mathrm{s}}=\left[\left(A_{\mathrm{r}} F_{\mathrm{s}} n_{\mathrm{s}}^{2}\right) /\left(A_{\mathrm{s}} F_{\mathrm{r}} n_{\mathrm{r}}^{2}\right)\right] \Phi_{\mathrm{r}}
$$

where $A$ is the absorbance at the excitation wavelength, $F$ the integrated emission area and $n$ is the refraction index of the solvents. Subscripts refer to the reference (r) or sample (s) compound. The absorbance value at excitation wavelength was always less than 0.1 , in order to avoid inner filter effects.

L-Tryptophan in aqueous phosphate buffer solution $(\mathrm{pH}=7.2)$ $\left(\Phi_{\mathrm{R}}=0.14 \text { at } 25^{\circ} \mathrm{C}\right)^{42}$ and fluorescein in $0.1 \mathrm{M} \mathrm{NaOH}$ solution $\left(\Phi_{R}=0.93 \text { at } 25{ }^{\circ} \mathrm{C}\right)^{43}$ were used as references for determination of the fluorescence quantum yield of the hydrogel and the dye curcumin incorporated into lipid vesicles, respectively.

The steady-state fluorescence anisotropy, $r$, is calculated by equation 2 ,

$$
r=\frac{I_{\mathrm{VV}}-G_{\mathrm{VH}}}{I_{\mathrm{VV}}+2 G I_{\mathrm{VH}}}
$$

where $I \mathrm{vv}$ and $I \mathrm{vH}$ are the intensities of the emission spectra obtained with vertical and horizontal polarization, respectively (for vertically polarized excitation light), and $G$ is the instrument correction factor,

$$
G={ }^{I} \mathrm{HV} / I_{\mathrm{HH}}
$$

where $I_{\mathrm{HV}}$ and $I_{\mathrm{HH}}$ are the emission intensities obtained with vertical and horizontal polarization (for horizontally polarized excitation light).

Förster Resonance Energy Transfer (FRET) measurements: The interaction of hydrogels with model membranes was investigated by FRET. FRET efficiency, $\Phi_{\text {RET }}$, defined as the proportion of donor molecules that have transferred their excess energy to acceptor molecules, can be obtained by taking the ratio of the donor integrated fluorescence intensities in the presence of acceptor $\left(\mathrm{F}_{\mathrm{DA}}\right)$ and in the absence of acceptor $\left(\mathrm{F}_{\mathrm{D}}\right)$ (equation 3),

$$
\Phi_{\mathrm{RET}}=1-\frac{\mathrm{F}_{\mathrm{DA}}}{\mathrm{F}_{\mathrm{D}}}
$$

The distance between donor and acceptor molecules can be determined through the FRET efficiency (equation 4),

$$
r_{\mathrm{AD}}=R_{0} \cdot\left[\frac{1-\Phi_{\mathrm{RET}}}{\Phi_{\mathrm{RET}}}\right]^{1 / 6}
$$

where $R_{0}$, Förster radius (critical distance), can be obtained from the spectral overlap, $J(\lambda)$, between the donor emission and the acceptor absorption, according to equations 5 and 6 (with $R_{0}$ in $\AA, \lambda$ in $\mathrm{nm}, \varepsilon_{\mathrm{A}}(\lambda)$ in $\left.\mathrm{m}^{-1} \mathrm{~cm}^{-1}\right)$

$$
R_{0}=0.2108\left[k^{2} \Phi_{D^{n}}^{0} /(\lambda)\right]^{\gamma / 6}
$$

$$
I(\lambda)=\int_{0}^{\infty \pi} I_{D}(\lambda) \varepsilon_{A}(\lambda) \lambda^{4} d \lambda
$$

Where $k^{2}=2 / 3$

is the orjentational factor assuming random orientation of the dyes, $\Phi_{D}^{0}$ is the fluorescence quantum yield of the donor in the absence of energy transfer, $n$ is the refraction index of the medium, $I_{\mathrm{D}}(\lambda)$ is the fluorescence spectrum of the donor normalized so that

$$
\int_{0}^{\infty} I_{D}(\lambda) d \lambda=\mathbf{1}
$$

and $\varepsilon_{\mathrm{A}}(\lambda)$ is the molar absorption coefficient of the acceptor. ${ }^{32}$

Circular dichroism: The CD spectra were recorded at $20^{\circ} \mathrm{C}$ on a Chirascan spectropolarimeter (Applied Photophysics, UK). Peptide hydrogels were loaded into $0.1 \mathrm{~mm}$ quartz cells. Spectra displaying absorbance $<2$ at any measured point, were acquired with $0.5 \mathrm{~nm}$ step, $1 \mathrm{~nm}$ bandwidth and 1 second collection time per step, taking three averages. The postacquisition smoothing tool from Chirascan software was used to remove random noise elements from the averaged spectra. A residual plot was generated for each curve to exclude distortion effects during the smoothing process. Following background correction, the $\mathrm{CD}$ data were normalized to molarmean residue ellipticity. 
Transmission electron microscopy: TEM experiments were performed using a Philips CM20 transmission electron microscope operated at $200 \mathrm{kV}$. The shiny side of 300 mesh $\mathrm{Cu}$ grids coated with a carbon film (Agar Scientific, UK) was placed over one drop of the peptide solution $(0.060 \mathrm{wt} \%$ in phosphate buffer $\mathrm{pH} 6,0.1 \mathrm{~m}$ ) for 1 minute. The excess solution was removed and the shiny side of the grid was placed over a drop of aqueous uranyl acetate (1 wt\%) (Agar Scientific, UK) for 1 minute. The excess solution was removed and the grid was allowed to dry at room temperture.

Rheology: Rheological experiments were performed on a PaarPhysica MCR300 stress-controlled rheometer, equipped with a temperature controlled Couette geometry (diameter 10 $\mathrm{mm})$. The hydrogel of peptide construct $(0.5 \mathrm{wt} \%$, phosphate buffer $\mathrm{pH} 6,0.1 \mathrm{~m}$ ) was heated to $65^{\circ} \mathrm{C}$ and transferred to the rheometer, pre-programmed to $65^{\circ} \mathrm{C}$. During the temperature cooling ramp $\left(5^{\circ} \mathrm{C} \mathrm{min}-1\right)$, the solution/gel was tested at $1 \mathrm{~Hz}$ and $0.5 \%$ strain. In the kinetic studies, the gel was sheared at 1 $\mathrm{Hz}, 0.5 \%$ strain and $20{ }^{\circ} \mathrm{C}$. Dynamic frequency sweeps were performed at $0.5 \%$ strain and $20^{\circ} \mathrm{C}$. During the strain sweep experiments the gel was submitted to different strains $(0.1$ to $500 \%)$, at constant frequency $(1 \mathrm{~Hz})$ and temperature $\left(20^{\circ} \mathrm{C}\right)$. For the second cycle, the rheometer was heated to $65^{\circ} \mathrm{C}$ and the cycle repeated.

MTT assay: Adult human skin fibroblasts (ASF-2 cells) were maintained at $37{ }^{\circ} \mathrm{C}$ in a humidified $5 \% \mathrm{CO}_{2}$ atmosphere grown in Dulbecco's Modified Eagle's Medium (DMEM, SigmaAldrich, St. Louis, MO, USA) supplemented with $10 \%$ fetal bovine serum (FBS, Lonza, Verviers, Belgium), $10 \mathrm{~mm}$ HEPES and $1 \%$ antibiotic/antimycotic solution (Sigma-Aldrich, St. Louis, MO, USA). Prior to culture, cells within a sub-confluent monolayer were trypsinized using trypsin (0.05\%)-EDTA.4Na $(0.53 \mathrm{~mm})$ solution and resuspended in DMEM to obtain a cell concentration of around 50000 cells per $\mathrm{mL}$. The cells were plated in 96-multiwell culture plates $(100 \mu \mathrm{L}$ per well $) 24$ hours before incubation. $5.0 \mathrm{~mm}$ peptide solutions in phosphate buffer $(0.1 \mathrm{~m}, \mathrm{pH})$ were used to prepare solutions of $50 \mu \mathrm{m}, 100 \mu \mathrm{m}$ and $500 \mu \mathrm{m}$ in DMEM. Solutions of phosphate buffer $(0.1 \mathrm{~m}$, $\mathrm{pH} 8$ ) at $1 \%, 2 \%$ and $10 \%$ in DMEM were used as controls. $100 \mu \mathrm{L}$ aliquots of buffer controls and peptide solutions were placed into the wells of the plate with the cell culture, with three replicas of each. The plate was incubated at $37{ }^{\circ} \mathrm{C}$ for 48 hours. Cells were then incubated for 60 minutes with MTT [3(4,5-dimethylthiazol-2-yl)-2,5-diphenyltetrazolium bromide, Sigma-Aldrich, St. Louis, MO, USA] to a final concentration of $0.5 \mathrm{mg} \mathrm{mL} \mathrm{m}^{-1}$. Then, the medium was removed, and the formazan crystals formed by the cell's capacity to reduce MTT were dissolved with a 50:50 (v/v) DMSO:ethanol solution, and absorbance measured at $570 \mathrm{~nm}$ (with background subtraction at $690 \mathrm{~nm}$ ), in a SpectroMax Plus384 absorbance microplate reader. The results were expressed as percentage relative to the control (cells with buffer solution).

Molecular dynamics simulations: The molecular structure of the RGD dehydropeptides were designed with the program PyMOL. ${ }^{44}$ The $\alpha, \beta$-dehydroamino acid, $\Delta \mathrm{Phe}$, was parameterized and validated in previous work by the authors, ${ }^{22,23}$ and the topology (bonded and non bonded parameters) was based on the equivalent encoded amino acid present in the GROMOS $54 \mathrm{a} 7$ force field. ${ }^{45}$ The peptides were designed in extended conformation and placed in dodecahedral boxes of water considering a hydration layer of at least $1.5 \mathrm{~nm}$ between the peptide and the walls in all directions; systems contain circa 3250-3300 water molecules. The Simple Point Charge (SPC) water model was used. ${ }^{46}$ Boxes were made neutral with the addition of one $\mathrm{Na}^{+}$ion. Each peptide was energy minimized with a steepest descent algorithm, and submitted to an equilibration step of $1 \mathrm{~ns}$. After that, a production run of $10 \mathrm{~ns}$ of NPT MD was perfomed at $310 \mathrm{~K}$ and 1 atm with a Berendsen bath with $\tau=0.10 \mathrm{ps}$. The SETTLE algorithm ${ }^{47}$ was used to constrain bond lengths and angles of water molecules, while the bond lengths and angles of peptides were constrained with the LINCS algorithm ${ }^{48}$ which allowed the use of a 2 fs timestep. For the treatment of long-range interactions, we used the reaction field method, with a cut-off of $1.4 \mathrm{~nm}$ and a dielectric constant of $\varepsilon=54$ (corresponding to SPC water). The van der Waals interactions were truncated with a twin-range cut-off of 0.8 and $1.4 \mathrm{~nm}$. All simulations were run with the GROMACS 4.5.4 software package. ${ }^{49}$ AutoDock $4.2^{38}$ was used to study the molecular recognition of peptide construct 4 by the $\alpha_{v} \beta_{3}$ integrin receptor. A detailed description of the experimental protocols used for the docking experiments can be found in the Supporting Information.

Proteolytic stability: Diluted solutions of peptide $4(300 \mu \mathrm{l} ; 0.5 \mathrm{mg}$ $\mathrm{mL}^{-1}$; phosphate buffer $\left.0.1 \mathrm{M}, \mathrm{pH} 7.5\right)$ were incubated in triplicate with $\alpha$-chymotrypsin (from bovine pancreas, type I-S, SigmaAldrich) $\left(300 \mu \mathrm{l} ; 0.5 \mathrm{mg} \mathrm{mL}^{-1} ; 51.3 \mathrm{U} \mathrm{mL}^{-1}\right)$. Samples were taken at 0 hrs, 2 hrs, 4 hrs, 8 hrs, 12 hrs, 24 hrs, 49 hrs and 78 hrs and analysed by HPLC ( $\lambda=276 \mathrm{~nm}$; water/acetonitrile, $1: 1$ with $0.1 \%$ TFA, flow rate $1.2 \mathrm{ml} . \mathrm{min}^{-1}$ ). The percentage of substrate (peptide 4) remaining was calculated by comparing the chromatographic area of the peak of peptide 4 (retention time $2.35 \mathrm{~min}$ ) at each time point with the area in solutions without chymotrypsin. The percentage of the proteolytic fragment was calculated by comparing the chromatographic area of the peak (retention time $3.30 \mathrm{~min}$ ) of the proteplytic fragment at each time point with the area of the proteolitic fragment after $49 \mathrm{hrs}$ (reaction complete). The hydrogelator block Npx- $L$-Ala- $\Delta \mathrm{Phe}-\mathrm{OH}$ (retention time $4.50 \mathrm{~min}$ ) was used as control. Non-enzymatic hydrolysis was excluded by analysing peptide solutions without chymotrypsin at each time point. To get insight into the structure of the proteolytic fragment reaction mixtures were analysed in triplicate at each time point by HPLC-MS (ESI, positive ionization) (water/acetonitrile, $1: 1$ with $0.1 \%$ formic acid; flow rate $0.4 \mathrm{~mL} \mathrm{~min}^{-1}$ ).

\section{Acknowledgements}

Thanks are due to Foundation for Science and Technology, FCTPortugal, for financial support through Centre of Chemistry of University of Minho (CQ-UM) (projects UID/QUI/00686/2013 and UID/QUI/00686/2016) and Centre of Physics of Minho and Porto Universities, CF-UM-UP (project UID/FIS/04650/2013) and project UID/CEC/00319/2013.. The NMR spectrometer Bruker Avance III 400 is part of the Portuguese NMR Network (Rede/1517/RMN/2005) which is also supported by FCT. Access to computing resources was funded by project NORTE-07-0162-FEDER-000086. TC acknowledges FCT PhD grant SFRH/BD/79195/2011.

\section{Notes and references}

${ }^{a}$ Centre of Chemistry, University of Minho, Campus de Gualtar, 4710-057 Braga, Portugal;

E-mail: pmf@quimica.uminho.pt; jmartins@quimica.uminho.pt 
${ }^{b}$ Centro ALGORITMI, University of Minho, Campus de Gualtar, 4710-057 Braga, Portugal

${ }^{c}$ Centre of Physics, University of Minho, Campus de Gualtar, 4710-057 Braga, Portugal.

${ }^{d}$ CICECO - Aveiro Institute of Materials, Department of Chemistry, University of Aveiro, 3810-193 Aveiro, Portugal

${ }^{e}$ Institute for Polymers and Composites/I3N, Department of Polymer Engineering, University of Minho,, Campus de Azurém, 4800-058 Guimarães, Portugal.

Department of Chemistry, University of Reading, Whiteknights, PO Box 224, Reading, RG6 6AD, UK

1- M. E. Gomes, M. T. Rodrigues, R. M. A. Domingues, R. L. Reis, Tissue Engineering Part B: Reviews, 2017, 23, 211.

2- B. N. Brown, S. F. Badylak, Transl. Res., 2014, 163, 268.

3- N. Eslahi, M. Abdorahim, A. Simchi, Biomacromolecules, 2016, 17, 3441.

4- X. Du, J. Zhou, J. Shi and B. Xu, Chem. Rev., 2015, 115, 13165

5- A. C. Mendes, E. T. Baran, R. L. Reis, H. S. Azevedo, WIREs Nanomed Nanobiotechnol., 2013, 5, 582.

6- D. Philp, J. F. Stoddart, Angew. Chem. Int. Ed. Engl., 1996, 35, 1154.

7- E. Gazit, Chem. Soc. Rev., 2007, 36, 1263.

8- a) G. Fichman, E. Gazit, Acta Biomaterialia, 2014, 10, 1671. b) M. Ikeda, T. Tanida, T. Yoshii, K. Kurotani, S. Onogi, K. Urayama, I. Hamachi, Nature Chemistry, 2014, 6, 511. c) Z. Zheng, P. Chen, M. Xie, C. Wu, Y. Luo, W. Wang, J. Jiang, G. Liang, J. Am. Chem. Soc., 2016, 138, 11128. d) H. Wang, Z. Luo, Y. Wang, T. He, C. Yang, C. Ren , L. Ma , C. Gong, X. Li , Z. Yang, Adv. Funct. Mater., 2016, 26, 1822 .

9- S. Fleming, R. V. Ulijn, Chem. Soc. Rev., 2014, 43, 8150.

10- K. M. Yamada, J. Biol. Chem., 1991, 266, 12809.

11- X. Li, X. Liu, B. Josey, C. J. Chou, Y. Tan, N. Zhang, X. Wen, Stem Cells Translational Medicine, 2014,. 3, 662.

12- C. C. Horgan, A. L. Rodriguez, R. Li, K. F. Bruggeman, N. Stupka, J. K. Raynes, L. Day, J. W. White, R. J. Williams, D. R. Nisbet, Acta Biomaterialia, 2016, 38, 11.

13- V. Jayawarna, S. M. Richardson, A. R. Hirst, N. W. Hodson, A. Saiani, J. E. Gough, R. V. Ulijn, Acta Biomaterialia., 2009, 5, 934.

14- W. T. Truong, Y. Su, D. Gloria, F. Braet, P. Thordarson, Biomater. Sci., 2015, 3, 298.

15- A. D. Martin, J. P. Wojciechowski, M. M. Bhadbhade, P. Thordarson, Langmuir: ACS J. Surf. Colloids, 2016, 32, 2245.

16- U. A. Ramagopal, S. Ramakumar, D. Sahal, V. S. Chauhan, Proc. Natl. Acad. Sci. U.S.A., 2001, 98, 870.

17- J. J. Panda, A. Mishra, A. Basu, V. S. Chauhan, Biomacromolecules 2008, 9, 2244.

18- J. J. Panda, R. Dua, A. Mishra, B. Mittra, V. S. Chauhan, ACS Applied Materials and Interfaces, 2010, 2, 2839.

19- J. Li, Y. Kuang, J. Shi, Y. Gao, J. Zhou, B. Xu, Beilstein J. Org. Chem., 2013, 9, 908.

20- J. Li, Y. Kuang, Y. Gao, X. Du, J. Shi, B. Xu, J. Am. Chem. Soc., 2013, 135, 542 .

21- Z. Chen, L. Xing, Q. Fan, A. G. Cheetham, R. Lin, B. Holt, L. Chen, Y. Xiao, H. Cui, Theranostics, 2017, 7, 2003.

22- H. Vilaça, G. Pereira, T. G. Castro, B. F. Hermenegildo, J. Shi, T. Q. Faria, N. Micaelo, R. M. M. Brito, B. Xu, E. M. S. Castanheira, J. A. Martins, P. M. T. Ferreira, J. Mater. Chem. B, 2015, 3, 6355.

23- H. Vilaça, A. C. L. Hortelão, E. M. S. Castanheira, M.-J. R. P. Queiroz, L. Hilliou, I. Hamley, J. A. Martins, P. M. T. Ferreira, Biomacromolecules, 2015, 16, 3562.
24- J. R. Kumita, C. J. Weston, L.-P. Choo-Smith,| G. A. Woolley, O. S. Smart, Biochemistry, 2003, 42, 4492.

25- R. Garifullin, M. O. Guler, Chem. Commun., 2015, 51, 12470.

26- R. J. Wade, J. A. Burdick, Materials Today, 2012, 15, 454

27- D. Gabriele, B. De Cindio, P. D'Antona, Rheol. Acta, 2001, 40, 120.

28- Z. Wei, J. H. Yang, J. X. Zhou, F. Xu, M. Zrinyi, P. H. Dussault, Y. Osada, Y. M. Chen, Chem. Soc. Rev., 2014, 43, 8114.

29- A. Goel, A. B. Kunnumakkara, B. B. Aggarwal, Biochem. Pharmacol. (Amsterdam, Neth.) 2008, 75, 787

30- G. Marslin, B. Sarmento, G. Franklin, J. A. Martins, C. Silva, A. Gomes, M. Sárria, O. Coutinho, A. Dias, Planta Med., 2017, 83, 434.

31- Y. Manolova, V. Deneva, L. Antonov, E. Drakalska, D. Momekova, N. Lambov,, Spectrochim. Acta A: Molec. Biomol. Spectrosc. 2014, 132, 815-820.

32- B. Valeur, Molecular Fluorescence - Principles and Applications, Wiley-VCH, Weinheim, 2002.

33- M. Montalti, L. S. Dolci, L. Prodi, N. Zaccheroni, M. C. A. Stuart, K. J. C. van Bommel, A. Friggeri, Langmuir, 2006, 22, 2299.

34- A. Barik, B. Mishra, A. Kunwar, K. I. Priyadarsini, Chemical Physics Letters, 2007, 436, 239.

35- J. Kremer, M. Esker, C. Pathmamanoharan, P. Wiersema, Biochemistry, 1977, 16, 3932

36- E. Feitosa, F. R. Alves, A. Niemiec, M. E. C. D. Real Oliveira, E. M. S. Castanheira, A. L. F. Baptista, Langmuir, 2006, 22, 3579.

37- Y. Sun, W. Li, X. Wu, N. Zhang, Y. Zhang, S. Ouyang, X. Song, X. Fang, R. Seeram, W. Xue, L. He, W. Wu, ACS Appl. Mater. Interfaces, 2016, 8, 2348 .

38- G. M. Morris, R. Huey, W. Lindstrom, M. F. Sanner, R. K. Belew, D. S. Goodsell, A. J. Olson, Journal of computational chemistry, 2009, 30, 2785 .

39- J.-P. Xiong, T. Stehle, R. Zhang, A. Joachimiak, M. Frech, S. L. Goodman, M. A. Arnaout, Science, 2002, 296, 151

40- X. Li, X. Du, Y. Gao, J. Shi, Y. Kuang, B. Xu, Soft Matter, 2012, 8, 7402.

41- J. N. Demas, G. A. Crosby, J. Phys. Chem., 1971, 75, 991.

42- E. P. Kirby, R. F. Steiner, J. Phys. Chem., 1970, 74, 4480.

43- D. Magde, R. Wong, P. G. Seybold, Photochem. Photobiol., 2002, 75, 327.

44- Schrödinger, The PyMOL Molecular Graphics System, 1.3r1; LLC: 2010

45- W. Huang, Z. X. Lin, W. F. van Gunsteren, J. Chem. Theory. Comput., 2011, 7, 1237.

46- H. J. C. Berendsen, J. R. Grigera, T. P. Straatsma, J. Phys. Chem., 1987, 91, 6269

47- D. van der Spoel, P. J. van Maaren, H. J. C. Berendsen, J. Chem. Phys., 1998, 108, 10220.

48- B. Hess, J. Chem. Theory Comput., 2008, 4, 116.

49- D. van der Spoel, E. Linddahl, B. Hess, A. R. van Buuren, E. Apol, P. J. Meulenhoff, D. P. Tieleman, A. L. T. M. Sijbers, K. A. Feenstra, R. van Drunen, H. J. C. Berendsen, Gromacs User Manual version 4.5.4., 2010. 
